\title{
NOTES
}

\section{UNIVERSAL HEALTHCARE AND ACCESS FOR UNDOCUMENTED IMMIGRANTS}

\author{
Samuel Wolbert
}

\begin{abstract}
INTRODUCTION
Nothing can rouse fury in even the most apathetic voter or stir the vitriol of American political discourse like the healthcare debate. From the run-up to the 2008 Presidential Election - when then-Senator Barack Obama made the creation of a revamped healthcare system the crux of his platform - through the present, the President's Patient Protection and Affordable Care Act ("PPACA") has been under siege. Obstreperous members of Congress on both sides of the debate levied traditional lines of criticism, concerning themselves with the law's perceived socialist leaning ${ }^{1}$ or the associated financial burden. ${ }^{2}$ Still other critics believe the healthcare plan will grant undocumented immigrants unmerited access to the benefits of a public healthcare system. Collectively, the narrative surrounding the healthcare debate has been so

* J.D. Candidate, May 2011, University of Pittsburgh School of Law. B.A., University of Michigan. I want to thank the entire editorial staff for reviewing drafts and providing helpful advice throughout this process. Also, I want to thank my family and friends for their support, especially my parents, Wayne and Nelda.

1. Steele Calls Obama 's Healthcare Socialism, Agrees This His Waterloo, The Huffington Post (July 20, 2009), http://www.huffingtonpost.com/2009/07/20/steele-calls-obama-health n 240989.html ("[When a]sked on Monday whether President Barack Obama's plan for health care reform represented socialism, RNC Chairman Michael Steele didn't waste words. 'Yes,' he declared").

2. Phil Kerpen, The Eye-Popping Cost of Obamacare, Foxnews.com (July 15, 2009), http://www.foxnews.com/opinion/2009/07/15/eye-popping-cost-obamacare/.
\end{abstract}


overly contentious and hostile as to obviate any remaining comity within the political discourse surrounding the problem. ${ }^{3}$ But, behind all this white noise and livid rhetoric there still remains the central issue: without an adequate proposal that addresses the undocumented immigrant 'problem,' President Obama's healthcare plan is incomplete.

Generally, hospitals would not turn anyone away from medical coverage in emergency situations, regardless of immigration status. Under the new healthcare plan, taxpayers still pay for coverage of those uninsured, undocumented immigrants seeking healthcare access for emergencies, just as they have done in the past. By not creating provisions for undocumented immigrants, the new plan effectively ignores one of the biggest problems that crippled our prior healthcare system. Thus, any healthcare plan that does not adequately cover undocumented immigrants would effectively minimize the cost-saving benefit of a program that purports to be universal.

This note will first address the flawed logic behind denying undocumented immigrants access to healthcare and, subsequently, it will address the reasons for healthcare inclusion. Next, the note will analyze the prior healthcare system vis-à-vis available care for undocumented immigrants and how it is comparable to the new plan. Finally, the note will suggest pragmatic solutions to this controversial issue by examining Mexico's universal healthcare system and also addressing a compromising 'middle ground' to the problem that calls for distributing healthcare to only undocumented children.

\section{Part I: The Narrative Surrounding Undocumented Immigrants and Possible Reasons for Exclusion}

To fully grasp the healthcare dilemma vis-à-vis undocumented immigrants, one must understand how such a substantial group can be entirely foreclosed from such an essential service. Undocumented immigrants can be denied access to even the most basic form of healthcare with little public outrage or moral guilt ${ }^{4}$ because they are, often times, wrongly perceived as criminals who disproportionately usurp public funds. In part, these

3. Emotions reached a boiling point when GOP Representative Joe Wilson yelled "You Lie!" at President Obama during a nationally aired speech the President gave to Congress.

4. See, e.g., Meredith L. King, Center for American Progress, Immigrants in the U.S. Health Care System, Five Myths That Misinform the American Public 7 (2007), http://www.americanprogress.org/ issues/2007/06/pdf/immigrant_health_report.pdf(A March 2006 Time Poll found that 75\% of Americans would deny undocumented immigrants government services such as health care.). 
misperceptions fuel the current rhetoric and political environment that allows for the denial of healthcare access to such a substantial group with little clamor from the public.

\section{A. The Perception of Undocumented Immigrants}

After 9/11 and the discovery that five out of the nineteen hijackers were in the United States illegally, ${ }^{5}$ the general public demanded a concentrated effort to fix immigration. Today, as the job market continues to stagnate and the American economy remains crippled by a recession, the discourse surrounding immigration has become an even more salient and germane concern for the American people. Throughout it all, the American public at large has turned a skeptical eye towards immigrants, particularly those immigrants here illegally.

The current public perception of undocumented immigrants is fueled by fear and mistrust. The image of the undocumented immigrant has been that of person whom we should chastise and exclude. ${ }^{6}$ Also, the language used in the immigration discourse mirrors language used in domestic criminal policy; terms such as "illegals" and "illegal aliens" reinforce the image of immigrants as nothing more than common criminals. ${ }^{7}$ The potency of this image is exacerbated by the threat of violence spilling over the American border. Now, the vast majority of undocumented immigrants are seen as gang-related and extremely dangerous. ${ }^{8}$

From a political perspective, giving healthcare to undocumented immigrants is not viewed as a benevolent hand-up to hard-working immigrants as much as it is seen as a poor allocation of funds to undeserving criminals. However, this perception is erroneous and should not be used as a justification for denying any healthcare services.

New studies are emerging which disprove the myth that undocumented immigrants create more crime. ${ }^{9}$ These studies show that, even though

5. Kris W. Kobach, Senate Bill Creates Terrorist Loophole, 62 Hum. Events 8, 8 (2006), available at $\mathrm{http}: / / \mathrm{www} \cdot$ humanevents.com/article.php?id=16048.

6. See, e.g., Mae Ngai, Impossible Subjects: Illegal Aliens and the Making of Modern America (2d ed. 2004).

7. Brietta R. Clark, The Immigrant Health Care Narrative and What It Tells Us About the U.S. Health Care System, 17 Ann. Health L. 229, 244 (2008).

8. Jennifer M. Chacon, Whose Community Shield: Examining the Removal of the "Criminal Street Gang Member," 2007 U. Chi. Legal F. 317, 318.

9. See, e.g., Ruxandra Guidi, Study Reveals Crime in California Drops as Immigration Increases, Oct. 18, 2010, available at http://www.kpbs.org/news/2010/oct/18/criminologist-says-crime-california- 
immigration continues to increase, cities with the highest immigration population have actually seen a substantial drop in homicide, robbery, and violent crime rates. ${ }^{10}$ For instance, San Diego, California has the lowest homicide rate out of every major urban area in the United States, ${ }^{11}$ despite being directly across the Mexican border. Other major cities in the Southwest, such as Phoenix, El Paso, and San Antonio, also, according to FBI data, continue to have declining crime rates. ${ }^{12}$ Overall, researchers are in agreement that there is "no support for the argument that immigrants are committing more crime and ... driving up the crime rate."13

These numbers contradict the assumption that undocumented immigrants are criminals. Based upon the results of these studies, at best undocumented immigrants may be tied to a reduction in crime, ${ }^{14}$ and at worst, they are no more dangerous than any other broadly-defined class of individuals. The misplaced stereotypes should not be allowed to dominate the public discourse surrounding undocumented immigrants nor should they be a reason for exclusion of healthcare benefits.

\section{B. Exponential Increase in Immigration Population as a Justification for Healthcare Exclusion}

Compounding the challenge of redefining the image of the undocumented immigrant is the fact that immigration levels have increased dramatically. As of 2007, one out of every eight people in the U.S. was an immigrant, which was the highest level in 80 years. ${ }^{15}$ Today, out of the 38 million immigrants in the United States, an estimated one-third are undocumented. ${ }^{16}$ The numbers of undocumented immigrants continue to increase; the Immigration and Naturalization Service (INS), since replaced with Immigration and Customs

drops-immigrat/; Christopher Dickey, Reading, Ranting, and Arithmetic, Newsweek, May 27, 2010, available at $\mathrm{http} / /$ www.kpbs.org/news/2010/oct/18/criminologist-says-crime-california-drops-immigrat/; Clay Latimer, Do Immigrants Reduce Crime?, ThE Coloradan, available at http://www .coloradanmagazine.org/2010/08/22/do-immigrants-reduce-crime/.

10. See Guidi, supra note 9; Latimer, supra note 9.

11. Latimer, supra note 9 .

12. Dickey, supra note 9 .

13. Latimer, supra note 9 .

14. See, e.g., Guidi, supra note 9; Dickey, supra note 9; Latimer, supra note 9.

15. Steven A. Camarota, Center for Immigration Studies, Immigrants in the United States, 2007: A Profile of America's Foreign-Born Population 1 (2007), available at http://www.cis.org/articles/ 2007/back1007.pdf.

16. Id. 
Enforcement (ICE), estimated that the undocumented immigrant population doubled between 1990 and 2000. ${ }^{17}$

Those who oppose inclusion argue that this exponential increase of undocumented immigrants will overly strain the healthcare system as they continue to abuse the system, usurp public funds, and freeload on the backs of Americans. This is simply unfounded. Statistics show that undocumented immigrants "contribute more to the revenue stream for U.S. social benefits than what they use." ${ }^{\prime 18}$ For example, undocumented workers contribute more than the average American to the social security system. ${ }^{19}$ Undocumented workers provide an estimated $\$ 7$ billion a year in Social Security tax revenues, despite the fact they will never collect on the benefits. ${ }^{20}$ They also contribute an estimated 1.5 billion in Medicare taxes annually, ${ }^{21}$ and the majority of undocumented workers pay payroll taxes. ${ }^{22}$

Furthermore, the amount of money undocumented workers are contributing to the revenue system is far greater than what they are taking out through public services. In Texas, a state with an enormous undocumented worker population, revenues collected from undocumented immigrants exceeded expenditures on these immigrants by $\$ 424.7$ million. ${ }^{23}$ This reflects nationwide statistics: for example, the National Research Council found that immigrants will pay an average of $\$ 80,000$ more in taxes than what they will use in services throughout the course of their lifetime. ${ }^{24}$

However, even under the assumption that the exponential increase in immigrants will disproportionally strain the healthcare system, it still makes sense to allow undocumented immigrants the same healthcare benefits as citizens. By allowing these individuals to pay into the new healthcare system, the costs of everyone's healthcare would be spread out across the entire population. ${ }^{25}$ Enabling undocumented immigrants to pay into the system would result in many new subscribers because non-citizens are the least likely

17. U.S. Gen. Accounting Office, Undocumented Aliens: Questions Persist about Their Impact on Hospitals Uncompensated Care Costs 5 (2004), available at http://www.gao.gov/new.items/d04472.pdf.

18. King, supra note 4, at 8.

19. Eduardo Porter, Illegal Immigrants Are Bolstering Social Security with Billions, N.Y. Times, Apr. 5, 2005, available at http://www.nytimes.com/2005/04/05/business/05immigration.html.

20. Id.

21. King, supra note 4 , at 8.

22. Porter, supra note 19 (estimating three-quarters of undocumented immigrants pay payroll taxes).

23. King, supra note 4 , at 8 .

24. Id.

25. Immigration Policy Center, Sharing the Costs, Sharing the Benefits: Inclusion Is the Best Medicine (2009), http://immigrationpolicy.pairsite.com/sites/default/files/docs/ Sharing\%20the \%20Costs\%20Sharing\%20the\%20Benefits\%202009.pdf. 
segment of Americans to be insured. ${ }^{26}$ The inclusion of undocumented immigrants would also likely reduce costs because immigrants, on the aggregate, are generally younger and healthier than U.S. citizens. ${ }^{27}$ As a result, undocumented immigrants are cheaper to insure, meaning they would help curb costs while not draining a disproportionate amount from the system.

Despite the misperception of immigrants as a burden on public services, these numbers reflect the fact that immigrants - both documented and undocumented - contribute more to U.S. revenue than what they take out. This is especially true for undocumented immigrants, who more often than not pay into Medicaid, payroll taxes, and social security payments, yet rarely reap the benefits. But, even assuming they are a disproportionate financial burden, it still is more beneficial to include undocumented workers in a healthcare system because they could help spread out the costs associated with healthcare.

With these misperceptions as a backdrop, one can see how a large, vocal opposition can justify restrictions to healthcare access for undocumented immigrants. If undocumented immigrants are to be granted access to healthcare, there needs to be a fundamental shift in the way these immigrants are perceived. Without it, undocumented immigrants will continue to be excluded from universal healthcare access, even at the detriment to the American society at large.

\section{Part II: Reasons to Grant Universal Healthcare Access to UNDOCUMENTED IMMIGRANTS}

By barring undocumented immigrants from buying into private health insurance the new healthcare system does nothing to ameliorate the financial strains created by an increasing amount of illegal immigration. Without a modified proposal that includes an improved policy towards undocumented immigrants, taxpayers will still ultimately pay for uninsured immigrants who choose to seek medical care. ${ }^{28}$

26. Fact Sheet, Kaiser Commission on Medicaid and the Uninsured, Summary: Five Basic Facts on Immigrants \& Their Health Care 1 (Mar. 11, 2008), available at http://www.kff.org/medicaid/upload/ 7761.pdf [hereinafter Summary: Five Basic Facts].

27. Sharing the Costs, supra note 25, at 3. See also Stephen Dinan, Liberals Seek Healthcare Access for Illegals, WASH. Times, Sept. 28, 2009, http://www.washingtontimes.com/news/2009/sep/28/ liberals-seek-health-care-access-for-illegals.

28. Susan Milligan, Health Care Opponents Intensify Late Attack, Boston Globe, Sept. 6, 2009, http://www.boston.com/news/nation/washington/articles/2009/11/06/health_care_opponents_intensify_ late_attack. 


\section{A. Denying Basic Medical Care Creates More Severe Problems}

When undocumented immigrants avoid seeing a physician or other healthcare provider, a basic medical condition can turn into a severe problem. As a basic medical condition worsens and the undocumented immigrant's health deteriorates, medical care becomes increasingly more expensive, forcing taxpayers to incur more costs..$^{29}$ In this manner, it makes financial sense to include basic coverage for illegal immigrants in a comprehensive healthcare plan.

Having more access to healthcare services would help undocumented immigrants manage chronic conditions, thereby avoiding higher related emergency room costs that could arise as the condition worsens. A coverage plan that includes undocumented immigrants would also encourage those individuals to take advantage of preventative care, which could in turn avoid the costs of more expensive emergency room care. ${ }^{30}$ Even President Obama acknowledges the necessity to support disease management programs $;{ }^{31}$ in his proposal he noted that seventy-five percent of the total healthcare expenditures are spent on patients with chronic conditions, an issue that could be fixed through disease management programs. ${ }^{32}$ If undocumented immigrants were able to take advantage of preventative programs or medication that would curb problems associated with chronic diseases, emergency room bills would inevitably be reduced. ${ }^{33}$

Barring undocumented immigrants from this type of program would ultimately undermine the new plan's cost saving measures and would result in higher costs for taxpayers, as the onus would be on the taxpayer to treat the immigrant's medical condition as it inevitably worsens.

\section{B. Undocumented Immigrant Healthcare Use Is Disproportionally Low}

Although many fear undocumented immigrants are taxing the healthcare resources, the reality is they are far less likely to use healthcare services than

29. King, supra note 4, at 7.

30. Tony Pugh, Medicaid Complicates Immigrant Debate; Program Now Requires Proof of Citizenship for Emergency Room Care, Contra Costa Times, July 1, 2006, available at LexisNexis Database for Contra Costa Times.

31. See Barack Obama \& Joe Biden, Plan to Lower Health Care Costs and Ensure Affordable Healthcare Coverage for All (2008), http://www.barackobama.com/pdf/issues/HealthCareFullPlan.pdf.

32. Id.

33. Pugh, supra note 30. 
U.S. citizens. ${ }^{34}$ The healthcare expenditures attributable to immigrants are also proportionally lower than expenditures attributable to United States citizens. ${ }^{35}$ In fact, the total healthcare costs attributable to undocumented immigrants are only $1.3 \%$ of all medical expenditures. ${ }^{36}$ Other data suggests that immigrants are much more likely to pay for their own healthcare than citizens, thereby undermining the view of immigrants as burden on the welfare system. ${ }^{37}$

Immigrants also rarely use emergency room services. ${ }^{38}$ The metropolitan areas of Miami-Dade, Phoenix, and Orange County, California are all urban areas with a much higher immigrant population than towns such as Cleveland and Little Rock, yet they experience far lower rates of emergency room use. ${ }^{39}$ Generally, this reflects the statistics that communities with the highest emergency room use do not necessarily have a large number of racial minorities, uninsured, or immigrant residents. ${ }^{40}$ Thus, contrary to popular perceptions, communities with higher immigrant populations actually have lower rates of emergency room use than areas with less immigration. ${ }^{41}$

Furthermore, fewer than ten percent of both documented and undocumented Mexican immigrants living in the United States for less than ten years reported using an emergency room, compared to twenty percent of native-born whites and Mexican-Americans. ${ }^{42}$ Even children in immigrant families use emergency room services disproportionally less than those in

34. King, supra note 4, at 5. See also Erin Fuchs, Medical Needs of Hispanics Targeted, Chattanooga Times/Free Press, July 29, 2007, http://www.timesfreepress.com/news/2007/jul/28/ Medical-needs-of-Hispanics-targeted; see also Nina Bernstein, Recourse Grows Slim for Immigrants Who Fall Ill, N.Y. Times, Mar. 3, 2006, at A1:

Immigrants have long been on the fringes of medical care. But in the last decade and especially since the terrorist attacks of Sept. 11,2001, steps to include them have faltered in a political climate increasingly hostile to those who face barriers of language, cost and fear of penalties like deportation, say immigrant health experts, providers, and patients. More and more immigrants are delaying care or retreating into a parallel universe of bootleg remedies and unlicensed practitioners.

35. Health Care Expenditures for Immigrants Are Lower Than for Citizens, NATIONAL IMMigRATion LAw CENTER (May 26, 2009), http://www.nilc.org/immspbs/health/costs-less-than-citz-200905-26.pdf [hereinafter Health Care Expenditures].

36. Id.

37. See Julia Preston, Immigration at Record Level, Analysis Finds, N.Y. Times, Nov. 29, 2007, at A20.

38. King, supra note 4 , at 7.

39. Id.

40. See Peter Cunningham, What Accounts for Differences in the Use of Hospital Emergency Departments Across U.S. Communities?, 25 Health AfFairs 5 (2006), available at http://content .healthaffairs.org/cgi/content/full/25/5/w324.

41. Health Care Expenditures, supra note 35.

42. King, supra note 4, at 5. 
citizen families, further dispelling the notion that people without access to primary care abuse emergency healthcare. ${ }^{43}$

Ultimately, the numbers reflect the reality that undocumented immigrants actually use healthcare services at a lower rate than native, U.S.-born citizens. This fact is reflected, in part, by immigrants' low use of emergency department services generally, but it also illustrates their apprehensions regarding the healthcare system. Often times, many undocumented immigrants do not seek medical attention - not due to any inherent toughness or being an efficient healthcare user - but rather, out of fear their immigration status will be revealed. Though, in the end, the distinction is immaterial; regardless of the reason, the fact remains that undocumented immigrants consume healthcare resources at lower rates than native, U.S.-born citizens.

\section{Undocumented Immigrant Healthcare Use Does Create Some Problems}

Undocumented immigrants might use healthcare services at a disproportionally lower rate than U.S. citizens but, nevertheless, hospitals are not immune from the financial burdens created by providing undocumented immigrants' with emergency room care. On the contrary, undocumented immigrants can still substantially affect the economic burdens of hospitals. ${ }^{44}$ The fact remains that undocumented immigrants rarely utilize healthcare services, but when they do choose to seek emergency medical care they are burdened with crippling emergency room fees. Since undocumented immigrants often cannot pay without adequate health insurance, the burden essentially falls on the hospitals.

Estimates of the total cost of unpaid medical bills attributable to undocumented immigrants are as much as $\$ 2$ billion per year..$^{45}$ As of 2003, in the Southwest alone undocumented immigrants accounted for an estimated $\$ 200$ million in unpaid medical care. ${ }^{46}$ Overall, this amount is a "blip on the national health screen," only amounting to a fraction of one percent of the

43. See Gabrielle Lessard \& Leighton Ku, Gaps in Coverage for Immigrant Families, 13 FutURE of CHILDREN 101, 107 (2003), available at http://futureofchildren.org/futureofchildren/publications/ docs/13_01_FullJournal.pdf/.

44. See, e.g., Michael Janofsky, Burden Grows for Southwest Hospitals, N.Y.TimEs, Apr. 14, 2003, at A14, available at 2003 WLNR 5219799. See also Dana Canedy, Hospitals Feeling Strain from Illegal Immigrants, N.Y. TIMES, Aug. 5, 2002, at 116, available at 2002 WLNR 4433048.

45. Canedy, supra note 44.

46. Janofsky, supra note 44. 
national healthcare budget. ${ }^{47}$ However, when these costs fall disproportionally on hospitals, that small fraction becomes financially devastating. ${ }^{48}$

As the country is facing increasing financial difficulties, states are forced to slash their budgets. As a result, the unpaid medical bills from undocumented immigrants are becoming increasingly burdensome on local hospitals. Some communities are eliminating nonemergency health services for undocumented immigrants, which could further shift the financial burden solely to the hospitals. ${ }^{49}$ To subsidize the rising costs of undocumented immigrant care, some hospitals have had to cut back on services they offer while simultaneously raising fees. ${ }^{50}$

Ultimately, undocumented immigrants are not disproportionally abusing the healthcare system, but nevertheless they do create some financial strain. Undocumented immigrants are in the United States and they do utilize healthcare services, usually after seemingly benign medical conditions have worsened. Thus, the reality of their healthcare use practically mandates inclusion in to the benefits of the new healthcare system.

\section{Part III: Juxtaposing the Prior Medicaid System with the PPACA}

Despite the flawed reasoning, the reasons for denying healthcare to undocumented immigrants are still prevalent today. The new healthcare legislation was passed as comprehensive reform specifically aimed at alleviating the systematic flaws of prior systems. However, with no provisions for addressing undocumented immigrants, the new healthcare plan is still marred by some of the same financial and ethical problems that plagued the previous system.

\section{A. Undocumented Immigrants, Emergency Medicaid, and Its Shortcomings}

Before President Obama's healthcare system became law, the federal government's general policy was to exclude undocumented immigrants from federal, state, and local benefit programs, ${ }^{51}$ with an exception for "Emergency

47. Jennifer Ludden, Healthcare Overhaul Ignores Illegal Immigrants, NATional Public RAdio (Feb. 20, 2010), http://www.npr.org/templates/story/story.php?storyld=106376595.

48. Id.

49. Anna Gorman, California Counties Cut Healthcare to Illegal Immigrants, L.A. TimEs, Apr. 27, 2009, http://articles.latimes.com/2009/apr/27/local/me-immighealth27.

50. Ludden, supra note 47.

51. 8 U.S.C. $\S \S 1611,1621$ (2006). 
Medicaid." ${ }^{52}$ Emergency Medicaid includes treatment for an "emergency medical condition," as long as the immigrant patient would otherwise meet the eligibility requirements for medical assistance under the particular state's medical plan. "Emergency medical condition" is defined as "a medical condition (including emergency labor and delivery) manifesting itself by acute symptoms of sufficient severity (including severe pain) such that the absence of immediate medical attention could reasonably be expected to result in placing the patient's health in serious jeopardy, serious impairment to bodily functions, or serious dysfunction of any bodily organ or part."

The courts are split over the correct interpretation of the "emergency medical" language, thereby blurring the scope of medical coverage for undocumented immigrants. ${ }^{55}$ The majority of federal courts agreed that undocumented immigrants arriving at a hospital with acute symptoms that, if left untreated, could result in serious bodily harm or death were entitled to Medicaid coverage to the "point of stabilization." ${ }^{56}$ A circuit split emerged when the courts attempted to define this arbitrary "point of stabilization." The courts generally declined to adopt a bright line test and therefore, were ambiguous when drawing the line between the end of stabilization and the start of post-stabilization assistance. ${ }^{57}$

Where the stabilization line was drawn led to financial repercussions for individual hospitals and created severe public policy implications. ${ }^{58}$ Undocumented immigrants are generally uninsured, ${ }^{59}$ unable to pay for expensive emergency room healthcare services, and barred from enrolling in Medicaid programs. ${ }^{60}$ As a result, individual hospitals were often left to cover

52. Sean Elliott, Note, Staying Within the Lines: The Question of Post-Stabilization Treatment for Illegal Immigrants under Emergency Medicaid, 24 J. Contemp. Health L. \& Pol'y 149, 151 (2007).

53. 42 U.S.C. $§ 1396 b(v)(2006)$.

54. Id.

55. Compare Szewczyk v. Dep't of Soc. Servs., 881 A.2d 259 (Conn. 2005) (patient still suffered from acute symptoms even after stabilization), with Greenery Rehab. Group v. Hammon, 150 F.3d 226 (2d Cir. 1998) (Medicaid coverage does not cover the treatment of illegal aliens for symptoms beyond stabilization).

56. Elliot, supra note 52, at 152.

57. Compare Diaz v. Div. of Soc. Servs., 628 S.E.2d 1, 5 (N.C. 2006) (patient not eligible to receive Medicaid coverage for post-stabilization therapy), with Scottsdale Healthcare, Inc. v. Ariz. Health Care Cost Containment Sys. Admin., 75 P.3d 91, 98 (Ariz. 2003) (Medicaid coverage may not always stop after the original injury is stabilized.).

58. Elliot, supra note 52, at 153.

59. Rand Corp., Rand Study Finds Undocumented Immigrants Are Most Likely to Be Uninsured (Nov. 10, 2005), http://www.rand.org/news/press.05/11.10.html.

60. Summary: Five Basic Facts, supra note 26. 
the uncompensated emergency room bill, ${ }^{61}$ leading to a financial strain and causing some hospitals without sufficient federal aid to go under. ${ }^{62}$ These hospitals were often faced with the dilemma of reducing treatments to save costs or helping a patient while hemorrhaging money. This notion of weighing a hospital's financial strain in treating uninsured immigrants against the costs of prohibiting certain medical treatments is a disturbing line for society to arbitrarily construct.

Under the prior system, emergency Medicaid attempted to help those in need of emergency care while reducing costs, yet it failed to successfully accomplish either goal. Hospitals still spent an exorbitant amount of money while typically leaving the patients' medical conditions unresolved. Depending upon where the capricious "stabilization" line was drawn by the courts, undocumented immigrants were sometimes purged from emergency room care when their ailments and healthcare conditions were not fully healed. Thus, the previous system was an expensive and inefficient program that failed to adequately resolve the financial and ethical issues stemming from undocumented immigrants.

\section{B. The Current Healthcare System}

Despite attempting to create a radically different healthcare system, the new healthcare plan, ${ }^{63}$ just like the old model, excludes undocumented immigrants. ${ }^{64}$ The legislative history also shows that Congressmen repeatedly stated that undocumented immigrants would be denied access to the plan's healthcare benefits. When debating the bill, the House Energy and Commerce Committee reiterated that undocumented immigrants are ineligible for Medicaid coverage, stating: "Nothing in this title shall change current prohibitions against Federal Medicaid ... on behalf of individuals who are not lawfully present in the United States." ${ }^{65}$

To ease concerns over undocumented immigration, the Obama administration supported language that would bar undocumented immigrants

\footnotetext{
61. Janofsky, supra note 44 .

62. Id.

63. The Patient Protection and Affordable Healthcare Act, available at http://www.govtrack.us/ congress/billtext.xpd?bill=h111-3590.

64. Allison Siskin \& Erica Lunder, Congressional Research Services, Treatment of Noncitizens in H.R. 3200, at 2 (2009), available at http://assets.opencrs.com/rpts/R40773_20090825.pdf\#page=2. See also Center for American Progress, Fact Check: Health Care \& Undocumented Immigrants (Sept. 11, 2009), http://www.americanprogress.org/issues/2009/09/immigration_health.html.

65. $I d$.
} 
from purchasing private health insurance as part of the proposed insurance exchanges. ${ }^{66}$ Also, with no public option plan in the bill, ${ }^{67}$ undocumented immigrants are forced to pay for their health costs out of pocket. Since the law also prohibits undocumented immigrants from receiving federal subsidies ${ }^{68}$ they are forced to pay full-price for health coverage, regardless of income levels. ${ }^{69}$ Therefore, under the new law, it is nearly impossible for most undocumented immigrants to afford the exorbitant healthcare prices.

Overall, the new healthcare law does nothing to alleviate the healthcare concerns regarding undocumented immigration. The result of the new healthcare plan is that undocumented immigrants probably cannot afford to pay for their emergency healthcare and hospitals will still have to rely on the antiquated emergency Medicaid scheme and the capricious definition of "stabilization" given by the courts. Even though the healthcare bill was lauded as a fundamental overhaul of an inefficient system, the law did nothing to address the problems caused by undocumented immigrants.

\section{Part IV: Pragmatic Solutions}

Instead of ignoring undocumented immigrants in the healthcare law, a realistic solution would acknowledge their presence and create a more inclusive healthcare system. However, assuming the status quo survives and the political climate remains unwelcoming towards a full-scale inclusion of all undocumented workers, there are still other options. Implementing even small changes to the healthcare law could save millions of dollars while moderately improving the overall health of undocumented immigrants.

\section{A. Case Study: Mexico's Healthcare System}

A number of pragmatic options exist, several of which would satisfy both sides of the healthcare debate. One such plan is found by looking across the southern border of the United States at the Mexican healthcare system. By studying the Mexican system, we may be provided with a diverse and unique solution to the current public debate. This note does not purport to represent

66. Milligan, supra note 28.

67. Nancy Pelosi Will Not Include Public Option in Final Bill, The Huffington Post, (Mar. 12, 2010), http://www.huffingtonpost.com/2010/03/12/pelosi-public-option_n_496559.html.

68. Jared Allen, Immigration May Threaten House Vote, The HiLl, Nov. 5, 2009, available at http://thehill.com/homenews/house/66649-immigration-threatens-vote.

69. Preston, supra note 37. 
the Mexican social welfare policies as the definitive approach; rather, the analysis relies upon pragmatic observations drawn from examining Mexico's attempts to cope with many of the same domestic issues present in the U.S. healthcare system.

Mexico's healthcare policy provides a unique case study for a variety of reasons. First, Mexico faces welfare and poverty issues that are much more pervasive than in any domestic region within the United States. Also, like the United States, Mexico is a bourgeoning home for immigrants. Mexico annually receives a large number of undocumented immigrants from surrounding countries. While this number does not exceed the immigration levels in the United States, it is nonetheless substantial for a country of its size, population, and resources. ${ }^{70}$ Thus, Mexico's solutions to its healthcare problems could provide a unique and practical perspective to the United State's dilemma.

Supplying healthcare to a developing country of over 105 million, such as Mexico, involves a complex system ranging from small, private insurance plans to a vast universal health insurance program that mixes public, private, and employer funding. ${ }^{71}$ Mexico's private health insurance system is not as prevalent as its counterpart in the United States: only about three million wealthy and middle class Mexicans are able to afford private care. However, those that can afford private healthcare do receive ample care at relatively cheap rates. ${ }^{72}$ Mexico also has a public system where about 50 million salaried Mexicans, along with their employers and government, pay into a progressive insurance scheme based on wage. ${ }^{73}$ Finally, and most importantly, is the universal healthcare system in Mexico.

In 2003, approximately 40 million uninsured Mexicans began receiving access to full health coverage through Mexico's universal healthcare system, the Seguro Popular de Salud (Social Health Insurance Program). ${ }^{74}$ The crux

70. James C. McKinley, Jr., Migrants Stream into South Mexico, N.Y. Times, Jan. 28, 2007, available at $\mathrm{http}: / / \mathrm{www} . n y t i m e s . c o m / 2007 / 01 / 28 /$ world/americas/28mexico.html. (Immigrants stream into Mexico in search of moving North into the U.S.).

71. Sheila Whyte, How Mexico's Health Care System Works, CBC News (May 4, 2009), available at http://www.cbc.ca/health/story/2009/05/04/f-health-mexico-health-system.html.

72. Id. (Explaining that Mexico's private health care system is booming, and it even attracts a plethora of Americans. Monterrey is a big center for medical tourism, where Americans can get an operation such as a hip replacement for as much as $\$ 50,000$ less than in the U.S.). See also Chris Hawley, Mexico's Health Care Lures Americans, USA Today, Sept. 1, 2009, available at http://www.usatoday.com/ news/world/2009-08-31-mexico-health-care_Nhtm.

73. Whyte, supra note 71.

74. Id. 
of the plan is to provide Mexicans with social health protection covering the most basic treatments, including 266 different types of general procedures and 312 medications. These basic treatments are provided to reduce catastrophic health expenditures, which can increase exponentially when standard preventative measures are ignored..$^{75}$ In exchange for access to these basic treatments, most families pay a premium based upon their income and then make preventative healthcare visits at clinics. ${ }^{76}$ The poorest $20 \%$ of the population pay nothing. ${ }^{77}$ Though the program is still in the nascent stages of implementation, early results have shown that catastrophic healthcare expenditures have declined for poor families and the general population as a whole. ${ }^{78}$ Equally as promising, these special programs have helped reduce malaria by sixty percent, tuberculosis mortality rates by thirty percent, and are on track to reduce child mortality by up to two-thirds by $2015 .^{79}$

To create a healthcare policy that is both effective and politically plausible, the United States should study the findings from Mexico's healthcare initiative and implement a policy that would push for basic and optional universal healthcare coverage. Many undocumented immigrants already pay taxes. ${ }^{80}$ An effective plan to cover their healthcare coverage while curbing costs would allow them to pay into a plan based on income earned and procedures covered. Through the access to basic care, the program could help subsidize crippling healthcare costs on the back-end. The positive effect of a similar program in Mexico cannot be ignored; healthcare costs have been reduced while providing healthcare access to individuals in extremely impoverished conditions.

75. Stephanie Brunner, Mexico's Universal Health Care Program Eases Crippling Household Expenses, Medical News Today, Apr. 8, 2009, available at http://www.medicalnewstoday.com/ articles/145527.php.

76. Whyte, supra note 71.

77. Id.

78. See, e.g., Whyte, supra note 71; Gary King et al., Public Policy for the Poor? A Randomised Assessment of the Mexican Universal Health Insurance Programme, 373 The LANCET 1447-54 (25 Apr. 2009) ("We found that the stewardship of Seguro Popular has been successful in reducing overall catastrophic and out-of-pocket expenditures for inpatient and outpatient medical procedures, especially in the poorest individuals").

79. Whyte, supra note 71.

80. See, e.g., Porter, supra note 19. 


\section{B. A Middle Ground: Providing Healthcare Only to Undocumented Children}

Mirroring the system in Mexico provides a potentially effective program to provide basic care to immigrants in order to avoid some of the debilitating costs associated with untreated ailments. Still other options exist. For instance, an effective way to curb healthcare costs while not providing full coverage for all undocumented immigrants is to offer basic coverage for children of undocumented immigrants. Providing healthcare for children at a young age is a crucial first step to healthy-living as an adult, and can help save costs associated with long-term diseases as the children mature.

As the fastest growing component of the United States' child population, ${ }^{81}$ immigrant children have significantly less access to healthcare when compared to their native peers.$^{82}$ Immigrant children are also more likely to be without a usual source of healthcare, relying instead on clinics and hospital emergency rooms as opposed to pediatric doctor offices. ${ }^{83}$ The numbers also show both undocumented children and U.S.-born children of undocumented parents use healthcare services at a much lower frequency than those children from non-immigrant parents. ${ }^{84}$ Out of those who do use healthcare services, approximately one-half rely on clinics or hospital outpatient centers as their primary source of care, and these providers are frequently strained by financial resources and only able to offer limited support. ${ }^{85}$ Consequently, when immigrant children do receive healthcare, it is usually of a lower quality than that received by similarly-aged children in citizen families. $^{86}$

The U.S. government has acknowledged the importance of providing more children with healthcare through the creation of programs such as the Children's Health Insurance Program (CHIP). CHIP covers uninsured children from families whose incomes are too high to qualify for Medicaid but too low

81. Randy Capps, Immigrant Families and Workers: The Health \& Well-Being of Young Children of Immigrants 1 (Urban Institute 2005), http://www.urban.org/UploadedPDF/311182_immigrant_ families_5.pdf.

82. See Lessard \& Ku, supra note 43

83. Capps, supra note 81 , at 3 ("More than twice as many young children of immigrants as natives lack a 'usual source of health care' ( 8 versus 3 percent).").

84. Arjit Nandi et al., Expanding the Universe of Universal Coverage: The Population Health Argument for Increasing Coverage for Immigrants, 11 J. ImmigRant MinoRity Health 433-36 (June 12, 2009).

85. Lessard \& Ku, supra note 43.

86. Id. 
to afford private health insurances. Until 2009, legal immigrants were generally barred from CHIP for five years after they entered the United States. ${ }^{87}$ That ban has since been lifted, however, CHIP still requires recipients to be U.S. citizens or legal residents; undocumented immigrants cannot qualify. The problem, though, is almost half of young, noncitizen children are undocumented, meaning they are ineligible for CHIP benefits, along with any other program except emergency Medicaid. ${ }^{88}$

Even when children of undocumented immigrants are eligible to receive healthcare coverage, undocumented families often do not enroll out of fear that receiving benefits might expose a family members' immigration status. ${ }^{89}$ Over one-quarter of immigrant children under the age of six have undocumented parents, meaning even if one parent is here legally, the fear of jeopardizing the other parent's status may be enough to avoid enrollment. ${ }^{90}$ This fear has become even more prevalent as consular officials have increasingly begun to scrutinize immigrants' use of healthcare. Today, immigrants who use health benefits are classified as "public charges," which can jeopardize their residency. ${ }^{91}$

Thus, the number of undocumented immigrant children is growing exponentially while at the same time they are kept from accessing healthcare services, either through the system itself or a parent's well-founded fear that their undocumented immigration status could be unveiled. Over time, this will likely create problems. For example, as children age, health-related concerns that manifested early in life will continually worsen. As they become adults, this will result in increased medical costs. An effective plan, therefore, would provide better healthcare to undocumented immigrant children in order to prevent aggravating any medical conditions.

A healthcare plan that provides universal care to all children is vital for numerous reasons. First, children depend on their parents for healthcare access. But, undocumented immigrants are most likely to be uninsured, meaning their children lack access to healthcare as well. Poverty rates for children of undocumented workers are also substantially higher than native families, thereby further preventing their access to satisfactory healthcare. ${ }^{92}$

87. Robert Pear, Obama Signs Children's Health Insurance Bill, N.Y. Times, Feb. 4, 2009, available at $\mathrm{http}: / / w w w . n y t i m e s . c o m / 2009 / 02 / 05 /$ us/politics/05health.html?_r=1\&ref=health.

88. Capps, supra note 81 , at 3 .

89. Lessard \& $\mathrm{Ku}$, supra note 43.

90. Capps, supra note 81 .

91. See Lessard \& Ku, supra note 43 , at 6 .

92. Donald J. Hernandez, Demographic Change and the Life Circumstances of Immigrant Families: The Future of Children: Children of Immigrant Families, Vol. 14 No. 2, Foundation for Child 
Healthcare coverage is the first step to quality healthcare, yet obtaining coverage is far more onerous for children in immigrant families than their native-born peers. ${ }^{93}$

Healthcare for children is also proportionally less expensive than healthcare for adults ${ }^{94}$ because children visit hospitals predominately for illnesses that are easily preventable or curable. ${ }^{95}$ For example, respiratory illnesses like pneumonia, bronchitis, and asthma, account for $\$ 3$ billion in healthcare costs - seven percent of total healthcare expenditures for children — but are relatively easy to prevent and cure. ${ }^{96}$ Access to proper preventive medicines, like inhaled or oral steroids, can greatly reduce the frequency and severity of asthma episodes but may not be available to children who lack a sufficient healthcare plan.

Children are in a unique situation when compared to adults because their care is usually more affordable and sometimes preventable. The government recognizes the importance of providing healthcare to children through programs like CHIP. CHIP, however, does not extend healthcare to undocumented children, many of whom are consistently being denied healthcare access at an alarming rate. Therefore, it is crucial to provide healthcare to children in general, and specifically to the undocumented immigrant children who are often unable to receive such care. Giving these children the access to healthcare at a young age could prevent complications and create a healthier community, thereby saving lives and reducing costs.

Development, http://fcd-us.org/uploadDocs/DJHPackard06_11_04.pdf.

93. Lessard \& Ku, supra note 43, at 7.

94. Pamela L. Owens et al., HCUP Fact Book No. 4, AHRQ Publication No. 04-000, Care of Children in US Hospitals 38 (2003), available at http://www.ahrq.gov/data/hcup/factbk4/ factbk4b.htm\#resource ("In total, children use 10 to 20 percent of all hospital resources compared to the 80 to 90 percent used by adults, as measured by hospital stays, length of hospitalization, and total charges.").

95. Heidi Schwarzwald, Seminars in Pediatric Infections Diseases April 2005, Illnesses Among Recently Immigrated Children 78-83 (vol. 16, issue 2), abstract available at http://www.journals .elsevierhealth.com/periodicals/yspid/article/PIIS1045187004001256/abstract ("Recent immigrant children have a higher likelihood of malnourishment and have an inadequate immunity to vaccine-preventable illnesses").

96. Owens, supra note 94 , at 37. 


\section{CONCLuSion}

As medical costs continue to increase, ${ }^{97}$ President Obama must still contend with detractors determined to minimize the impact of the PPACA. The healthcare law, though, is incomplete because it effectively bars undocumented immigrants from receiving any of the benefits, including universal or reduced-cost healthcare. Any cost-saving provision in the plan is undermined without an access requirement for undocumented immigrants.

Despite an emphasis on broad, over-reaching initiatives designed to curb undocumented immigration, undocumented immigrants are here in the United States. Not only will they remain here but their numbers will very likely increase over time. A robust healthcare debate that ignores their presence or skirts the issue does nothing to alleviate the problem. Therefore, a healthcare plan that prohibits undocumented immigrants from accessing any healthcare benefits will continue to be marred with financial problems and ethical difficulties.

97. John Fritze, Medical Expenses Have “Very Steep Rate of Growth, ”USA TodAY, Feb. 2, 2010, available at $\mathrm{http}: / / \mathrm{www} . u$ uatoday.com/news/health/2010-02-04-health-care-costs_Nhtm. 